\title{
THE CAREER ADAPT-ABILITIES SCALE- INDONESIAN FORM: PSYCHOMETRIC PROPERTIES AND CONSTRUCT VALIDITY
}

\author{
Wiwik Sulistiani ${ }^{*}$, Dewi Retno Suminar ${ }^{2}$ and Wiwin Hendriani ${ }^{2}$ \\ ${ }^{1}$ Faculty of psychology, Universitas Hang Tuah, Indonesia \\ ${ }^{2}$ Faculty of psychology, Universitas Airlangga, Indonesia
}

\begin{abstract}
Studying in college, students start thinking about the future, going to work after graduation, thinking of the desired job. Students learn about the various jobs that can be occupied according to the current education. Career development is very important all along. This study examines the psychometric behavior of career adaptation (CAAS) in Indonesia. CAAS consists of four subscales, each with six items to measure concern, control, curiosity and confidence. Participants in this study were students at one university in Surabaya, Indonesia $(\mathrm{N}=281)$. This study analyzes the goodness of fit conceptual model on the students, validity and reliability of instrument discriminant. Test validity using Confirmatory Factor Analysis (CFA), and test reliability using Alpha Cronbach. The results provide strong psychometric support for CAAS-Indonesian Forms with a student subject as a valid measure to analyze their career adaptability. The factor structure of the CAAS-Indonesia is similar to the hierarchical four-factor model of the CAASInternational.
\end{abstract}

Keywords: Career adaptability, Career construction model, Psychometric properties Indonesia, college student

\section{Introduction}

A developmental stage between adolescence and adulthood is the emerging adulthood (Arnett, 2003). In this stage, each individual encounter developmental task to make decisions in term of their life commitment. Among others is career choice for future life (Schwartz, Côté, \& Arnett, 2005). In general, one should be in college around this age. College students are at a point of their life in which they have to think about a career of their choice and how to achieve it (Chong \& Leong, 2017). According to Super (1980), issues about career do not only happen to employed individuals, but to adolescents when they prepare themselves for career pursuit. Further, Skorikov (2007) suggests that lack of career preparation can have both direct and indirect effect on vocational problems.

As Buyukgoze-kavas (2014) reported, among the critical career issues in higher education are job decision and adaptation skill. Career adaptability plays an important role in career planning (Savickas \& Porfeli, 2012; Savickas, 2009). Findings from previous studies show that career adaptability in education will affect academic satisfaction (Buyukgoze-kavas, Duffy, \& Douglass, 2015, Hirschi, 2009); life satisfaction (Santilli, Marcionetti, \& Nota, 2017), and academic achievement (i.e. Grand Point Academic) (Negru-subtirica \& Pop, 2016). Individuals with strong future orientation have strong career planning as well, so they will perform better in college and vice versa (Negru-subtirica \& Pop, 2016). A study by Merino-tejedor, Hontangas, and Boada-grau (2016) found that career adaptability correlated with academic fatigue and academic involvement. It implies that individuals with high career adaptability are inclined to highly involved in educational process at campus, in term of both academic and non-academic activities. 


\section{Indonesian Context}

Geographically, Indonesia is situated in between two continents, namely Asia and Australia and is also located in between two oceans, Indian Ocean and Pacific Ocean. Indonesia is an archipelago rich in cultures, ethnicities, customs, arts, attires, and languages. Regardless, the diversities are unified into one entity, hence the national motto "Bhineka Tunggal Ika" which means "unity in diversity". Also, Bahasa Indonesia is the lingua franca of Indonesia.

Indonesia is a developing country, so career issue is a relevant and important issue to discuss. How individuals choose a job, how to prepare themselves for their career of choice, how to achieve the favored career are deemed as individual responsibilities. Economic problems and labor challenges in today's globalization era urge people to be able to adapt to careers. A common problem is career adaptability in transitional period.

Indonesia is well-known for its highly collectivistic culture. According to Sawitri and Creed (2015), in term of career, Indonesia has collectivistic contexts. In collectivistic cultures, many activities are intended to show respects for others, for instance to make parents proud and satisfied including in choosing a career. Hence, career adaptability is a vital facet for Indonesian students. Students get into college with various background stories, such as choosing a particular major to respect parents' choice, or to make them proud although the students themselves are lacking of personal interest in the particular major.

Therefore, students in college are facing issues with their career choice and career adaptability which resulted from their decision about their education and career of choice that is affected by their environment. In order to deal with this problem, individual adaptability is necessary for students to be able to feel comfort during their study and to eventually achieve success both in education and working life. A longitudinal study showed that adolescents with better career adaptability were more like to succeed in mastering vocational transition (Creed, Muller, \& Patton, 2003). Vocational refers to individual response in choosing and adapting to the opted university program (Savickas in Brown, 2002). Transition, in this case, is a change pertaining to the educational demands and the learned skills in education which relate to careers.

\section{Career adaptability}

Adaptability is "the quality of being able to change, without great difficulty, to fit new or changed circumstances" (Savickas, 2007). Further, adaptability is conceptualized as the ability or resource that individuals have to behave while facing a changing condition. It helps individuals to shape their strategy in directing adaptive behavior (Savickas \& Porfeli, 2012). Career adaptability is a concept describing individual's ability to make decision about planning and self-efficacy to succeed in transition of selecting a major in university (Creed et al, 2003). In addition, Savickas (2007) explains that career adaptability is a psychosocial construct which indicates individual resource to deal with current task and to anticipate development, occupational transition, and occupational trauma which, to a great or lesser degree, change individual's social integrity.

There are four dimensions of career adaptability which shape individual's strategy to flexibly act when dealing with career assignment. They are concern, control, curiosity, and confidence. Concern is the care about the future which helps one to see forward and prepare for what might happen next. Control enables individual to be responsible to shape themselves and their environment to meet what might happen next through self-discipline, effort, and perseverance. Possible selves and alternative scenarios are explored when curiosity encourages oneself to think about themselves in various situations and roles. The experience of such exploration and information-seeking activities might results in some aspirations and builds one's confidence that they can actualize choices to implement their life design (Porfeli \& Savickas, 2012). 


\section{Career Adapt-Adaptabilities Scale}

An internationally standardized measure to assess career adaptability is Career Adapt-Abilities Scale (CAAS). The CAAS has been tested internationally in 13 countries and proven to have great reliability for its application in several different cultural contexts. CAAS-International version consists of 24 items, comprising four dimensions, namely concern, control, curiosity, and confidence (Porfeli \& Savickas, 2012). This scale has also been used in a number of researches in educational contexts across various nations and shown good validity and reliability (Buyukgoze-kavas, 2014; Guan et al, 2015; Merino-tejedor et al, 2016; Olugbade, 2016; Tian \& Fan, 2014). However, Porfeli and Savickas (2012) reported that cross-cultural and cross-lingual differences are indeed an important factor affecting the scale's validity and reliability.

\section{Research Objective}

The objective of this research is to test the psychometric properties, such as item statistics and internal consistency estimates, of CAAS-Indonesian Form in order to determine its usability in Indonesian culture.

\section{Method}

\section{Participant}

Participants in this research were 281 students of a private university in Surabaya Indonesia, consisting of 151 males and 130 females. The age of participants ranged from 17 to 22 years old.

\section{Procedure}

Data collection was conducted through direct questionnaire completion. Data was collected in classrooms following lectures and after permissions were obtained from the lecturers. Authors provided guidelines to fill out the questionnaire and waited until all participants finished completing it.

\section{Measures}

Career adaptability was measured using Indonesian version of CAAS (Savickas \& Porfeli, 2012). The adaptation procedure complied with the steps suggested by Wild et al (2005). The initial step was preparation, wherein authors reviewed literatures concerning career adaptability. In some articles, authors found the CAASInternational Form (Savickas \& Porfeli, 2012). The second step was forward translation, in which the CAAS was translated from English to Indonesian. Two expert translators were involved, one of them is a lecturer with psychology background and the other is a lecturer with an English background. Both translations were conducted separately. The third step was reconciliation, where the two translations were assessed in term of their equality and were then discussed with a moderator. After the discussion with a moderator, a single version of translation was agreed upon. Then the fourth step was back translation. The Indonesian translation of the CAAS was translated back to English by a professional translator. The following step was harmonization, in which the back translation was compared with the original version of the scale. The comparison showed that there were some differences in word selection, but after a recheck on the meaning of the differing words, those words actually share the same meanings, hence needed to be aligned. The next step was cognitive debriefing, in this step the translated CAAS was given to two students and a lecturer for them to read and to understand, so it would ensure that the diction is understandable for students. Author also conducted interviews with those three people concerning the translated items. The final steps were review of cognitive debriefing results and finalization, wherein the responses from the three readers were analyzed which resulted in a version that can be well understood. 
The CAAS-Indonesian Form was developed based on the CAAS International Form 2.0 (Savickas \& Porfeli, 2012) which consists of 24 items to assess individual's career adaptability. The 24 items are divided equally into four subscales representing each dimension of career adaptability, namely career concern, career control, career curiosity, and career confidence. The response set uses five-point Likert scaling, ranging from 1 (not strong) to 5 (strongest)

Savickas and Porfeli (2012) reported the internal consistency reliability of the CAAS-International Form for each dimension as follow: 0.83 (career concern), 0.74 (career control), 0.79 (career curiosity), and 0.85 (career confidence); and also 0.92 for all items. In this research, the reliability estimate of the CAAS-Indonesian Form as a whole is 0.91 . For each subscale, the estimates are as follow: 0.84 (career concern), 0.85 (career control), 0.83 (career curiosity), and 0.84 (career confidence). Table 1 provides details of the reliability estimates.

Table 1 Career Adapt Abilities Scale (CAAS)-Indonesian Form: Item Descriptive Statistics, and standardized factor loadings

\begin{tabular}{|c|c|c|c|c|c|c|c|}
\hline Construct & & Item (first order indicator) & Indonesian translation & Mean & SD & $\begin{array}{l}\text { Loading } \\
\text { factor }\end{array}$ & $\alpha$ \\
\hline \multirow[t]{6}{*}{ Concern } & 1 & $\begin{array}{l}\text { Thinking about what my } \\
\text { future will be like }\end{array}$ & $\begin{array}{l}\text { Memikirkan seperti apa } \\
\text { masa depan saya kelak }\end{array}$ & 4.39 & 0.76 & 0.63 & 0.84 \\
\hline & 2 & $\begin{array}{l}\text { Realizing that today's } \\
\text { choices shape my future }\end{array}$ & $\begin{array}{l}\text { Menyadari bahwa } \\
\text { pilihan di hari ini } \\
\text { menentukan masa depan } \\
\text { saya }\end{array}$ & 4.23 & 0.91 & 0.59 & \\
\hline & 3 & Preparing for the future & $\begin{array}{l}\text { Menyiapkan masa depan } \\
\text { saya }\end{array}$ & 4.25 & 0.87 & 0.76 & \\
\hline & 4 & $\begin{array}{l}\text { Becoming aware of the } \\
\text { educational and career } \\
\text { choices that I must make }\end{array}$ & $\begin{array}{l}\text { Menjadi peduli pada } \\
\text { pilihan pendidikan dan } \\
\text { kejuruan yang harus } \\
\text { saya tempuh }\end{array}$ & 3.97 & 0.87 & 0.65 & \\
\hline & 5 & $\begin{array}{l}\text { Planning how to achieve } \\
\text { my goals }\end{array}$ & $\begin{array}{l}\text { Merencanakan } \\
\text { bagaimana cara } \\
\text { mencapai tujuan saya }\end{array}$ & 4.07 & 0.85 & 0.77 & \\
\hline & 6 & $\begin{array}{l}\text { Concerned about my } \\
\text { career }\end{array}$ & $\begin{array}{l}\text { Memperhatikan } \\
\text { mengenai karier saya }\end{array}$ & 4.13 & 0.85 & 0.75 & \\
\hline \multirow[t]{6}{*}{ Control } & 7 & Keeping upbeat & Tetap Optimis & 4.19 & 0.91 & 0.65 & 0.85 \\
\hline & 8 & $\begin{array}{l}\text { Making decisions by } \\
\text { myself }\end{array}$ & $\begin{array}{l}\text { Membuat keputusan saya } \\
\text { sendiri }\end{array}$ & 3.69 & 0.93 & 0.66 & \\
\hline & 9 & $\begin{array}{l}\text { Taking responsibility for } \\
\text { my actions }\end{array}$ & $\begin{array}{l}\text { Bertanggung jawab atas } \\
\text { tindakan saya }\end{array}$ & 4.09 & 0.89 & 0.73 & \\
\hline & 10 & Sticking up for my beliefs & $\begin{array}{l}\text { Mempertahankan } \\
\text { kepercayaan saya }\end{array}$ & 4.04 & 0.96 & 0.79 & \\
\hline & 11 & Counting on myself & Mempercayai diri sendiri & 4.07 & 1.01 & 0.77 & \\
\hline & 12 & Doing what's right for me & $\begin{array}{l}\text { Melakukan apa yang } \\
\text { baik menurut saya }\end{array}$ & 4.08 & 0.89 & 0.66 & \\
\hline \multirow[t]{3}{*}{ Curiosity } & 13 & $\begin{array}{l}\text { Exploring my } \\
\text { surroundings }\end{array}$ & $\begin{array}{l}\text { Mengeksplorasi } \\
\text { lingkungan sekitar }\end{array}$ & 3.58 & 1.00 & 0.57 & 0.83 \\
\hline & 14 & $\begin{array}{l}\text { Looking for opportunities } \\
\text { to grow as a person }\end{array}$ & $\begin{array}{l}\text { Mencari kesempatan } \\
\text { untuk berkembang } \\
\text { sebagai seorang individu }\end{array}$ & 3.70 & 1.04 & 0.60 & \\
\hline & 15 & Investigating options & Mencari tahu alternatif & 3.62 & 0.94 & 0.67 & \\
\hline
\end{tabular}


Proceeding of the $4^{\text {th }}$ International Conference on Education, Vol. 4, Issue 2, 2018, pp. 1-9

\begin{tabular}{|c|c|c|c|c|c|c|c|}
\hline & & before making a choice & $\begin{array}{l}\text { sebelum menentukan } \\
\text { pilihan }\end{array}$ & & & & \\
\hline & 16 & $\begin{array}{l}\text { Observing different ways } \\
\text { of doing things }\end{array}$ & $\begin{array}{l}\text { Mengamati cara-cara } \\
\text { yang berbeda dalam } \\
\text { melakukan sesuatu }\end{array}$ & 3.64 & 0.97 & 0.76 & \\
\hline & 17 & $\begin{array}{l}\text { Probing deeply into } \\
\text { questions I have }\end{array}$ & $\begin{array}{l}\text { Menggali lebih dalam } \\
\text { pertanyaan yang saya } \\
\text { miliki }\end{array}$ & 3.53 & 0.98 & 0.75 & \\
\hline & 18 & $\begin{array}{l}\text { Becoming curious about } \\
\text { new opportunities }\end{array}$ & $\begin{array}{l}\text { Ingin tahu tentang } \\
\text { peluang-peluang baru }\end{array}$ & 3.99 & 0.88 & 0.70 & \\
\hline \multirow[t]{7}{*}{ Confidence } & 19 & $\begin{array}{l}\text { Performing tasks } \\
\text { efficiently }\end{array}$ & $\begin{array}{l}\text { Mengerjakan tugas } \\
\text { secara efisien }\end{array}$ & 3.56 & 0.95 & 0.71 & \multirow[t]{6}{*}{0.84} \\
\hline & 20 & $\begin{array}{l}\text { Taking care to do things } \\
\text { well }\end{array}$ & $\begin{array}{l}\text { Berhati-hati dalam } \\
\text { melakukan sesuatu } \\
\text { dengan baik }\end{array}$ & 3.91 & 0.90 & 0.70 & \\
\hline & 21 & Learning new skills & $\begin{array}{l}\text { Mempelajari } \\
\text { keterampilan baru }\end{array}$ & 3.77 & 0.94 & 0.72 & \\
\hline & 22 & Working up to my ability & $\begin{array}{l}\text { Bekerja hingga batas } \\
\text { kemampuan saya }\end{array}$ & 3.85 & 0.95 & 0.61 & \\
\hline & 23 & Overcoming obstacles & Menaklukkan rintangan & 3.77 & 0.98 & 0.71 & \\
\hline & 24 & Solving problems & Menyelesaikan masalah & 3.93 & 0.96 & 0.72 & \\
\hline & & \multicolumn{2}{|c|}{ Construct (second-order indicators) } & & & & \\
\hline \multirow{4}{*}{$\begin{array}{l}\text { Career } \\
\text { Adaptability }\end{array}$} & 1 & Concern & & 4.17 & 3.86 & 0.79 & \multirow[t]{4}{*}{0.91} \\
\hline & 2 & Control & & 4.02 & 4.30 & 0.89 & \\
\hline & 3 & Curiosity & & 3.67 & 4.28 & 0.85 & \\
\hline & 4 & Confidence & & 3.79 & 2.31 & 0.88 & \\
\hline
\end{tabular}

Result

\section{Confirmatory Factor Analysis}

Confirmatory factor analysis (CFA) was conducted to test whether the grouping of the indicators of career adaptability based on theoretical construct was consistent when implemented on a sample of Indonesian students (Sarjono \& Julianita, 2015). Referring to the original article of CAAS-International Form (Savickas \& Porfeli, 2012), hierarchical model was constructed from four subscales of CAAS and one general factor of career adaptability. CFA showed that the data of CAAS-Indonesian Form was consistent with its proposed theoretical model. Model fit indices are as follow: $\chi^{2}=494.23$; $\mathrm{df}=128 ; \mathrm{p} \geq .05$; RMSEA $=.06$; GFI $=.87$; AGFI= .84; $\mathrm{CFI}=098$. The loading factors of each subscale shown in Table 1 suggest that all items are strong indicators of the second order constructs, which in turn are also strong indicators of career adaptability.

\section{Model factor of the CAAS Indonesia and Model Factor of the CAAS International}

The loading factors of items in CAAS-Indonesian Form are similar to those of CAAS-International Form. In the CAAS-Indonesian Form, the factor loading of the first item of concern subscale ("Thinking about what my future will be like") was 0.63 , the first item of control subscale ("Keeping upbeat") was 0.65 , the first item of curiosity subscale ("Exploring my surroundings") was 0.57, and the first item of confidence subscale ("Performing tasks efficiently") was 0.71 . Meanwhile in the CAAS-International Form, they were respectively 0.65 (concern), 0.48 (control), 0.62 (curiosity), and 0.60 (confidence). The loading factors of control and confidence in the CAAS-Indonesian sample were higher than those of CAAS-International. 
The factor loading of the second item of concern subscales ("Realizing that today's choices shape my future") was 0.59 , that of control's second item ("Making decision by myself") was 0.66 , that of curiosity's second item ("Looking for opportunities to grow as a person") was 0.60 , and that of confidence's second item ("Performing tasks efficiently") was 0.71 in the sample for CAAS-Indonesian Form. In the CAAS-International, the factor loadings were respectively 0.61 (concern), 0.58 (control), 0.69 (curiosity), and 0.66 (confidence). The loading factors of control and confidence subscale were higher in CAAS-Indonesian sample compared to those in CAAS-International sample.

If compared as a whole scale, the loading factor of control subscale in CAAS-Indonesian Form was higher than that of CAAS-International Form.

Loading factors of the second-order constructs in CAAS-Indonesian Form were 0.79 for concern, 0.89 for control, 0.85 for curiosity, and 0.88 for confidence, while in CAAS-International Form, they were 0.78 for concern, 0.86 for control, 0.88 for curiosity, and 0.90 for confidence. Overall, the loading factors of concern and control construct in CAAS-Indonesian Form were higher than in CAAS-International Form. 


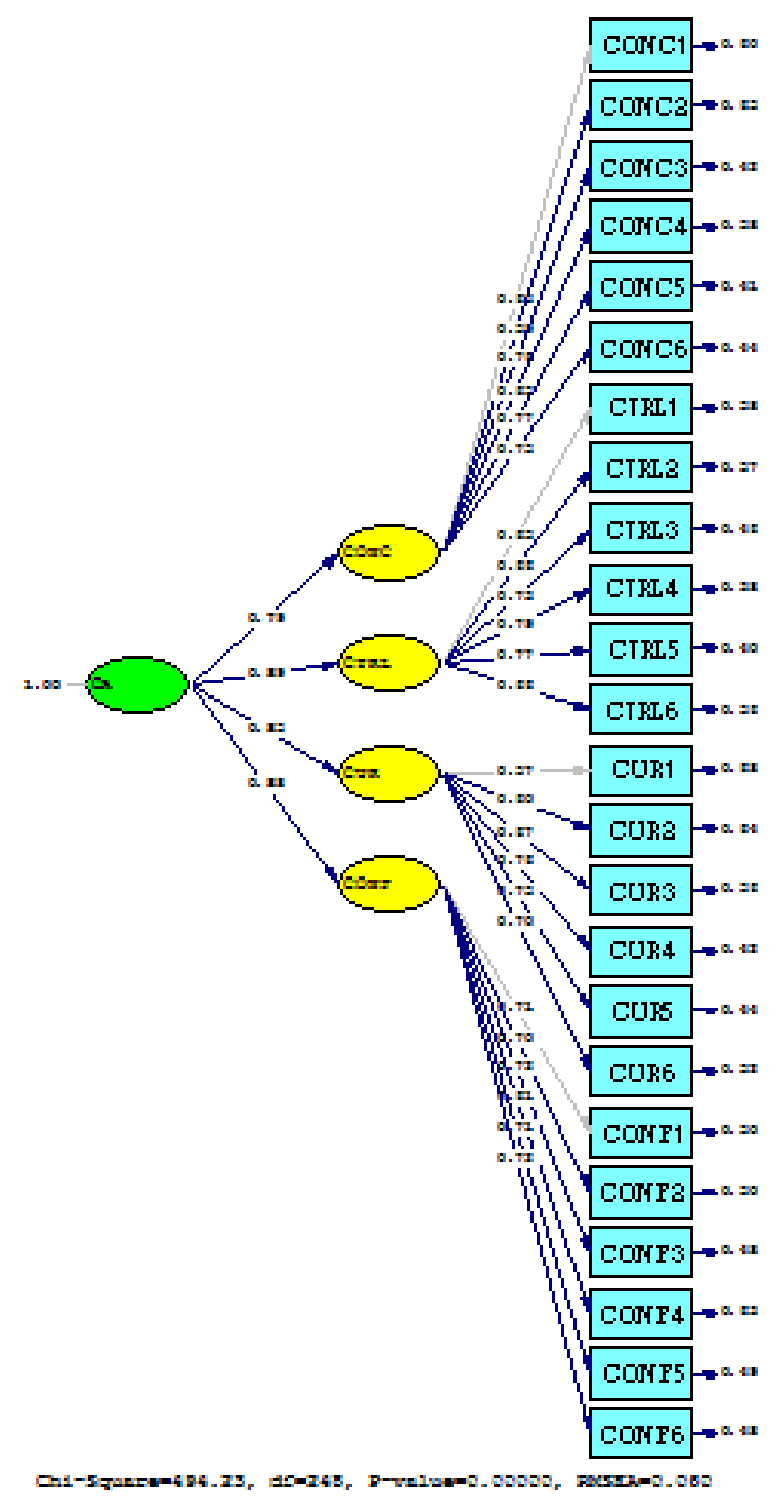

Figure 1 Measurement model of CAAS-Indonesia

\section{Discussion}

This research aimed to test the psychometric properties of CAAS-Indonesian Form in student sample. Statistical analysis provided evidence that CAAS-Indonesian Form shares similar with CAAS-International Form in term of factor structure and psychometric properties. The whole scale of career adaptability and its four subscales showed good internal consistency estimate in accordance with the proposed theoretical model. This finding enables further in-depth exploration of psychometric properties of the CAAS-Indonesian Form. It also suggests that CAAS-Indonesian Form can be used by researchers, psychologists, and career counselor to assess student's career adaptability in Indonesia.

The results also show that the loading factors of each item in control subscale of CAAS-Indonesia were higher than those of CAAS-International. The overall control subscale also had higher loading compared to other subscales. It suggests that Indonesian students had higher degree of control in preparing the future of their career. Individuals feel responsible to shape themselves and their environment to meet the career demands using self-discipline, effort, and perseverance. Career context in Indonesia which demands each individual to face 
competition in workplace seems to have driven individual to put a great deal of effort in controlling themselves so that they can actualize their desire for success in career.

\section{Conclusion}

The result of this research shows that the CAAS-Indonesian Form and the CAAS-International Form have the same function. This finding can be used for researchers and practitioners who are interested to assess career adaptability in students, both for research or career counseling purposes.

\section{References}

Buyukgoze-Kavas, A. (2014). Validation of the career adapt-abilities scale-Turkish form and its relation to hope and optimism. Australian Journal of Career Development, 23, 125-132. http://dx.doi.org/10.1177/1038416214531931

Buyukgoze-Kavas, A., Duffy, R. D., \& Douglass, R. P. (2015). Exploring links between career adaptability, work volition, and well-being among Turkish students. Journal of Vocational Behavior, 90, 122-131. http://dx.doi.org/10.1016/j.jvb.2015.08.006

Chong, S. \& Leong, F.T., (2017). Antecedents of career adaptability in strategic career management. Journal of Career Assessment, 25(2), pp.268-280. https://doi.org/10.1177/1069072715621522

Creed, P. A., Muller, J., \& Patton, W. (2003). Leaving high school: The influence and consequences for psychological well-being and career-related confidence. Journal of Adolescence, 26, 295-311. Retrieved from http://dx.doi.org/10.1016/S0140-1971(03)00015-0

Guan, Y., Wang, F., Liu, H., Ji, Y., Jia, X., Fang, Z., ... Li, C. (2015a). Career-specific parental behaviors, career exploration and career adaptability: A three-wave investigation among Chinese undergraduates. Journal of Vocational Behavior, 86, 95-103. http://dx.doi.org/10.1016/j.jvb.2014.10.007

Merino-Tejedor, E., Hontangas, P. M., \& Boada-Grau, J. (2016). Career adaptability and its relation to selfregulation, career construction, and academic engagement among Spanish university students. Journal of Vocational Behavior, 93, 92-102. http://dx.doi.org/10.1016/j.jvb.2016.01.005.

Negru-Subtirica, O., \& Pop, E. I. (2016). Longitudinal links between career adaptability and academic achievement in adolescence. Journal of Vocational Behavior, 93, 163-170. http://dx.doi.org/10.1016/j.jvb.2016.02.006

Olugbade, O.A., (2016). The career adapt-abilities scale - Nigeria form: Psychometric properties and construct validity. Journal of Vocational Behavior, 95, pp.111-114. https://doi.org/10.1016/j.jvb.2016.08.006

Porfeli, E. J., \& Savickas, M. L. (2012). Career Adapt-Abilities Scale-USA Form: Psychometric properties and relation to vocational identity. Journal of Vocational Behavior, 80(3), 748-753. http://dx.doi.org/10.1016/j.jvb.2012.01.009.

Santilli, S., Marcionetti, J., Rochat, S., Rossier, J. \& Nota, L., (2017). Career adaptability, hope, optimism, and life satisfaction in Italian and Swiss adolescents. Journal of Career Development, 44(1), pp.62-76. https://doi.org/10.1177/0894845316633793

Sarjono, H., \& Julianita, W., (2015). Structural Equation Modeling (SEM). Jakarta: Salemba Empat.

Savickas, M. L. (1997). Career adaptability: An integrative construct for life-span, life-space theory. Career Development Quarterly, 45, 247-259. http://dx.doi.org/10.1002/j.2161-0045.1997.tb00469.x

Savickas, M. L. (2002). Career construction: A developmental theory of vocational behavior. In D. Brown (Ed.), Career choice and development (pp. 149-205) (4th ed). San Francisco: Jossey-Bass.

Savickas, M. L., \& Porfeli, E. J. (2012). Career Adapt-Abilities cale: Construction, reliability, and measurement equivalence across 13 countries. Journal of Vocational Behavior, 80(3), 661-673. http://dx.doi.org/10.1016/j.jvb.2012.01.011

Schwartz, S. J., Côté, J. E., \& Arnett, J. J., 2005. Identity and agency in emerging adulthood: two developmental routes in the individualization process. Youth \& Society Vol. 37 No. 2, December 2005 201-229 https://doi.org/10.1177/0044118X05275965

Skorikov, V., 2007. Continuity in adolescent career preparation and its effects on adjustment. Journal of Vocational Behavior, 70(1), pp.8-24. https://doi.org/10.1016/j.jvb.2006.04.007 
Tian, Y., \& Fan, X. (2014). Adversity quotients, environmental variables and career adaptability in student nurses. Journal of Vocational Behavior, 85, 251-257. http://dx.doi.org/10.1016/j.jvb.2014.07.006

Wild, D., Grove, A., Martin, M., Eremenco, S., McElroy, S., Verjee-Lorenz, A. and Erikson, P., 2005. Principles of good practice for the translation and cultural adaptation process for patient-reported outcomes (PRO) measures: report of the ISPOR Task Force for Translation and Cultural Adaptation. Value in health, 8(2), pp.94-104. https://doi.org/10.1111/j.1524-4733.2005.04054. 